\title{
Fiscal Decentralisation and Economic Development in Selected Unitary European Countries
}

\author{
Irena Szarowská*
}

\section{Introduction}

Scope of fiscal decentralisation and intergovernmental fiscal frameworks usually reflect fundamental societal choices and history and are not foremost geared towards achieving economic policy objectives. Fiscal relations affect the behaviour of firms, households and governments and thereby economic activity. Firms' investment decisions are affected by the productivity of the public sector, and differences between costs and benefits of service provision across jurisdictions may induce them to change their location. Similarly, labour supply decisions by households will be affected by differences in taxation across jurisdictions, and households may migrate if they consider the ratio of services received in relation to taxes paid superior elsewhere. The combined actions of households and firms may in turn lead to policy reactions at both the national and sub-national level, triggering reforms to intergovernmental fiscal relations (OECD, 2014).

Fiscal decentralisation, which involves the devolution of government fiscal responsibilities to lower (sub-central) governments, has been discussed in many countries. A reason for this interest is the theoretical prediction that fiscal decentralisation enhances the efficiency of government and promotes economic development (Oates, 1993).

\footnotetext{
\# The article was supported by the Ministry of Education, Youth and Sports Czech Republic within the Institutional Support for Long-term Development of a Research Organization in 2014.

Ing. Irena Szarowská, Ph.D. - Assistant Professor; Department of Finance and Accounting, School of Business Administration in Karviná, Silesian University in Opava, Univerzitní nám. 1934/3, 73340 Karviná, Czech Republic; <szarowska@opf.slu.cz>.
} 
The aim of the article is to provide direct empirical evidence on fiscal decentralisation and economic development in selected European countries in a period $1995-2012$. The examination will be performed on a panel, which contains 17 unitary countries. Since fiscal decentralisation has many dimensions, the following indicators will be used in the empirical analysis: spending decentralisation, revenue decentralisation and tax revenue decentralisation.

\section{Literature Review and Theoretical Background}

Fiscal decentralisation is often discussed as a political issue in many countries, but the term is not sufficiently clear even in the fields of political science or public administration. Generally, fiscal decentralisation is linked to sharing of fiscal responsibilities and power among central, state and local governments. Akai and Sakala (2002) define fiscal decentralisation as devolution of the authority associated with decision making to a lower-level government. To measure fiscal decentralisation, it is necessary to know the degree of devolution or the level of authority of the lower-level government. Authority associated with decision-making has been allocated on the basis of legal relationships between higher and lower-levels government. However, it is difficult to measure the allocation of authority quantitatively. In Thiessen's (2003) point of view, fiscal decentralisation considers a transfer of responsibility associated with accountability to sub-national governments. He maintains that fiscal decentralisation is considered as the potential of sub-national governments to increase tax revenues, and make decision how to allocate their monetary resources on various projects within the legal boundary. Bird and Wallich (1993) note that fiscal decentralisation is observed as a portion of reform package for improving public sector efficiency, to raise competition among lower level government in supplying public goods and to accelerate economic growth.

As OECD (2013) points out, there are numerous channels through which fiscal decentralisation and an intergovernmental set-up affects an economy. Figure 1 illustrates some of the ways in which fiscal decentralisation can affect economic activity and development. In a macroeconomic production function, output is determined by physical and human capital and by their productivity, known as total factor productivity. Productivity in the private and public sector is, in turn, 
affected by institutional and policy settings like the extent of decentralisation. Since firms and households rely on public sector services, corporate productivity and household well-being may depend on how and where governments spend money. Fiscal frameworks might, for example, shape the extent to which governments - both national and sub-national - invest in infrastructure or education. Finally, fiscal decentralisation may directly affect a particular public sector (e.g. education system) whose performance can affect human capital formation.

\section{Fig. 1: Channels from decentralisation to economic activity}

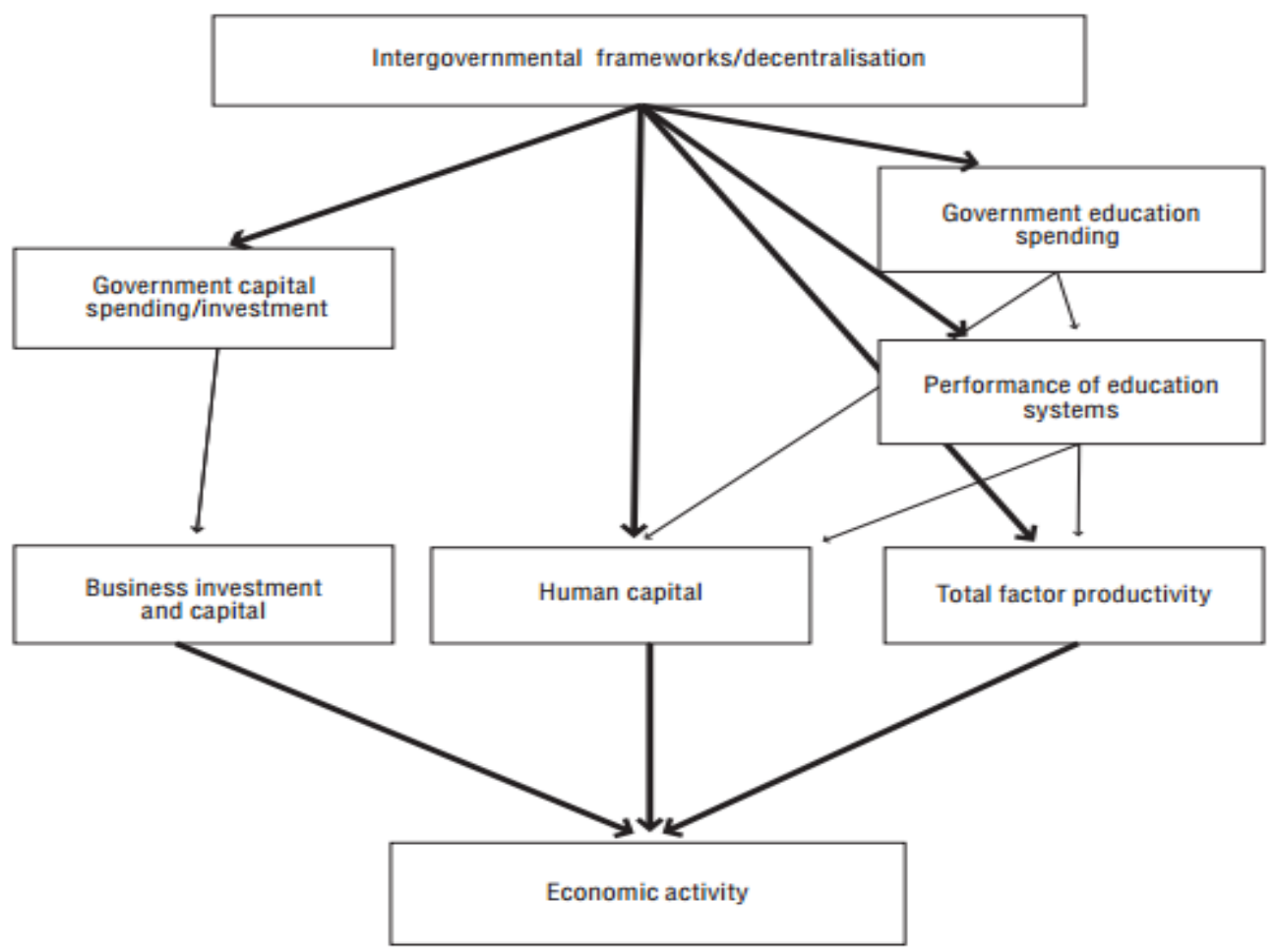

Source: OECD (2013).

Rodríguez-Pose and Krøijer (2009) summarize arguments in favour of fiscal decentralisation. They claim it promotes higher efficiency, better public service, greater transparency and, eventually, economic growth. It is often argued that decentralisation increases economic efficiency because local governments are better positioned than the national 
government to deliver public services as a result of proximity and informational advantage. This proximity is particularly important in lowincome countries or emerging markets where in absence of market opportunities, vulnerable populations rely heavily on state action for their survival.

Thornton (2007) highlights that the relationship between fiscal decentralisation and long-run economic growth is ambiguous as is apparent from the results of empirical studies. Several economists have made the case for fiscal decentralisation as means of promoting long-run economic growth based on the view that leads to better resource allocation and more productive, and possibly smaller, public sector. This might be because locally determined policies are better able to take account of regional and local conditions in the provision of public goods, such as infrastructure and education (Oates, 1993), or that competition among different levels of government promotes lower tax rates and the efficient production of public goods under revenue constraints (Brennan and Buchanan, 1980). Vazquez and McNab (2003) conclude that it provides incentives for local governments to innovate in the production and supply of public goods and services. Contrary, Tanzi (1995) argues that fiscal decentralisation can create for macroeconomic policy coordination generally, and for implementing stabilization policies in particular.

Empirical studies focused on the relationship between fiscal decentralisation and economic growth provide mixed results. Blöchliger and Égert (2013) present a comprehensive overview of literature review, which is divided into two groups - cross-country studies and national studies. Most empirical studies are focused on the share of subnational government revenue or expenditure in consolidated (national and subnational) government revenue or expenditure as the measure of fiscal decentralisation. Studies that have reported a positive and statistically significant impact using these measures include, among others, Iimi (2005), who reports a significant and positive impact of expenditure decentralisation on per capita GDP growth in a panel of 51 developed and developing countries covering $1997-2001$.

Akai and Sakata (2002) find that the ratios of local government revenue and expenditure to combined state and local government revenue and expenditure have a positive and statistically significant impact on state GDP in a panel study of US states covering $1992-1996$. 
Also Thiessen (2003) describes a positive relation between decentralisation and growth when decentralisation is increasing from low levels, but that as decentralisation increased, the relation eventually turned negative in a cross section of high-income OECD economies using annual data for a period $1973-1998$.

There is a group of studies that have found no statistically significant relation between growth and fiscal decentralisation. For instance, Thornton (2007) notes that recent studies examining the relation between fiscal decentralisation and economic growth have failed to take account of the extent of the independent taxing powers available to sub-national governments and thus have substantially overstated the degree of effective decentralisation. Results from his cross section study of 19 OECD member countries suggest that when the measure of fiscal decentralisation is limited to the revenues over which sub-national governments have full autonomy, its impact on economic growth is not statistically significant. Davoodi and Zou (1998) have similar conclusions and present negative but not statistically significant effect of expenditure decentralisation on economic growth for developing countries and no clear relationship for developed countries using panel data for 46 developed and developing countries covering the period 1970-1989.

Contrary to a majority view, it is possible to find many empirical studies with proven a negative impact of fiscal decentralisation on economic growth. Zhang and Zou (1998) demonstrate how the allocation of fiscal resources between the central and local governments has affected economic growth in China since reforms began in the late 1970s. They find that a higher degree of fiscal decentralisation of government spending is associated with lower provincial economic growth over the past fifteen years.

As well Rodríguez-Pose and Krøijer (2009) examine, using a panel data approach with dynamic effects, the relationship between the level of fiscal decentralisation and economic growth rates across 16 Central and Eastern European countries over the 1990 - 2004 period. Their findings suggest that there is a significant negative relationship between two out of three fiscal decentralisation indicators included in the analysis and economic growth. However, the use of different time lags allows them to nuance this negative view and show that long-term effects vary depending on the type of decentralisation undertaken in each of the countries considered. While expenditure and transfers to subnational tiers 
of government are negatively correlated with economic growth, tax as assigned at the subnational level evolve from having a significantly negative to a significantly positive correlation with the national growth rate. This supports the view that subnational governments with their own revenue source respond better to local demands and promote greater economic efficiency.

Next Rodríguez-Pose and Ezcurra (2011) analyse the relationship between decentralisation and economic growth in 21 OECD countries during the period between 1990 and 2005 and controlling not only for fiscal decentralisation, but also for political and administrative decentralisation. The results point towards a negative and significant association between fiscal decentralisation and economic growth in the sample countries, a relationship that is robust to the inclusion of a series of control variables and to differences in expenditure preferences by subnational governments. The impact of political and administrative decentralisation on economic growth is weaker and sensitive to the definition and measurement of political decentralisation.

Gemmell et al. (2013) investigate whether the efficiency gains accompanying fiscal decentralisation generate higher growth in more decentralized economies, applying pooled-mean group techniques to a panel dataset of 23 OECD countries, 1972 - 2005. They find that spending decentralisation tends to be associated with lower economic growth while revenue decentralisation is associated with higher growth. Since OECD countries are substantially more spending than revenue decentralized, this is consistent with Oates' (1993) hypothesis that maximum efficiency gains require a close match between spending and revenue decentralisation. It suggests reducing expenditure decentralisation, and simultaneously increasing the fraction financed locally, would be growth-enhancing.

Also Baskaran and Feld (2013) examine the effect of fiscal decentralisation on economic growth for twenty-three OECD countries from 1975 to 2008. In order to proxy fiscal decentralisation, they use both traditional Government Finance Statistics (GFS) - style measures and new measures that account for the degree of subnational tax autonomy. The regressions with GFS-style measures indicate that fiscal decentralisation has a negative but statistically insignificant effect on growth. Regressions with the new measures also result in negative 
coefficient estimates. However, they are larger in absolute terms and statistically significant.

Some studies even consider decentralisation harmful, especially in the case of developing and transition economies (Rodden, 2002). This scepticism is fuelled by problems often associated with decentralisation, such as increasing deficits, lower quality of government decisions, corruption, increased influence of interest groups, and greater interregional inequalities, which may result in lower overall economic growth.

For the empirical literature on fiscal federalism, these results imply that measures of fiscal decentralisation that account for subnational tax autonomy should be preferred to traditional GFS-style measures. From a policy perspective, they conclude that policy makers should be aware of the economic trade-offs when pursuing reforms toward more fiscal decentralisation.

\section{Data and Methodology}

The aim of the paper is to provide direct empirical evidence on fiscal decentralisation and economic development in selected European countries in a period $1995-2012$ (the newest available data are from 2012). This empirical examination is performed for 17 unitary EU countries, namely Czech Republic (CZ), Denmark (DK), Estonia (ES), Finland (FI), France (FR), Greece (GR), Hungary (HU), Ireland (IR), Italy (IT), Luxembourg (LU), Netherlands (NL), Poland (PO), Portugal (PT), Slovak Republic (SK), Slovenia (SV), Sweden (SW) and United Kingdom (UK). The analysis uses data taken from OECD Fiscal Decentralisation Database and OECD, that's why a selection of analysed countries is limited to their membership in the OECD.

Since fiscal decentralisation has many dimensions, the following indicators are used in the empirical analysis: expenditure decentralisation, revenue decentralisation and tax revenue decentralisation. The variables are specified in following form:

- expenditure decentralisation (EXPD) is the ratio of sub-central to total general government spending, 
- revenue decentralisation (REVD) means the ratio of subcentral own revenue to total general government revenue,

- tax revenue decentralisation (TAXD) expressing the ratio of sub-central tax revenue to total general government tax revenue,

- economic development is assessed using the real GDP growth rate (RGDP) and nominal GDP per capita (GDP) expressed in Purchasing Power Standard per inhabitant.

It is needful to test the stationary time series before starting analysis. Unit root tests identified that time series are stationary at the first differences (RGDP also at level data). Therefore it is not possible to use level data. The first differences of variables were estimated and are used in the model (GDP time series are first converted into logs).

Explanatory variables are chosen in accordance to Blöchliger (2013). They are not examined in individual regressions, but analysis newly uses Generalized Method of Moments (Dynamic Panel Data). The basic panel models are defined in (1) and (2) and variables are explained above:

$$
\begin{aligned}
\Delta R G D P_{i t}= & \alpha_{i}^{*}+\beta_{1} * \Delta E X P D_{i t}+\beta_{2} * \Delta R E V D_{i t}+\beta_{3} * \Delta T A X D_{i t}+ \\
& +\beta_{4} * \Delta F R I_{i t}+u_{i t} \\
\Delta G D P_{i t}= & \alpha_{i} *+\beta_{1} * \Delta E X P D_{i t}+\beta_{2} * \Delta R E V D_{i t}+\beta_{3} * \Delta T A X D_{i t}+ \\
& +\beta_{4} * \Delta F R I_{i t}+u_{i t}
\end{aligned}
$$

The constants are specific to the $\mathrm{i}$-th unit (country) at time $\mathrm{t}$, at the same time but are constant. $\beta^{\prime}$ is the vector dimension $1 \times \mathrm{KK}$ constants and $\alpha i^{*}$ is a constant representing the effects of those variables, which are characteristic of the $i$-th observation. Unit error component represents non-significant effects of variables inherent in the i-team observations and a given time interval.

The generalized method of moments (GMM) is a generic method for estimating parameters in statistical models. Usually it is applied in the context of semi parametric models, where the parameter of interest is finite-dimensional, whereas the full shape of the distribution function of the data may not be known. GMM is popular in estimating structural economic models, as it requires much less conditions on model 
disturbances than Maximum Likelihood. Another important advantage is that it is easy to obtain parameter estimates that are robust to heteroscedasticity of unknown form (Hansen, 1982). For a model specification, Dynamic Panel Data Model Wizard is applied. The wizard aids in specifying a member of the class of dynamic panel data models with fixed effects. These models are designed for panels with a large number of cross-sections and a shorter time series (Arellano and Bond, 1991).

\section{Results and Discussion}

The country sample covers 17 unitary EU countries with central and local governments. The degree of decentralisation varies widely across countries but has changed little over the reported period, with a few notable exceptions. As Figure 2 shows, there are significant differences among scope of fiscal decentralisation in countries and variables.

Fig. 2: Fiscal decentralisation in 2012 (in \%)

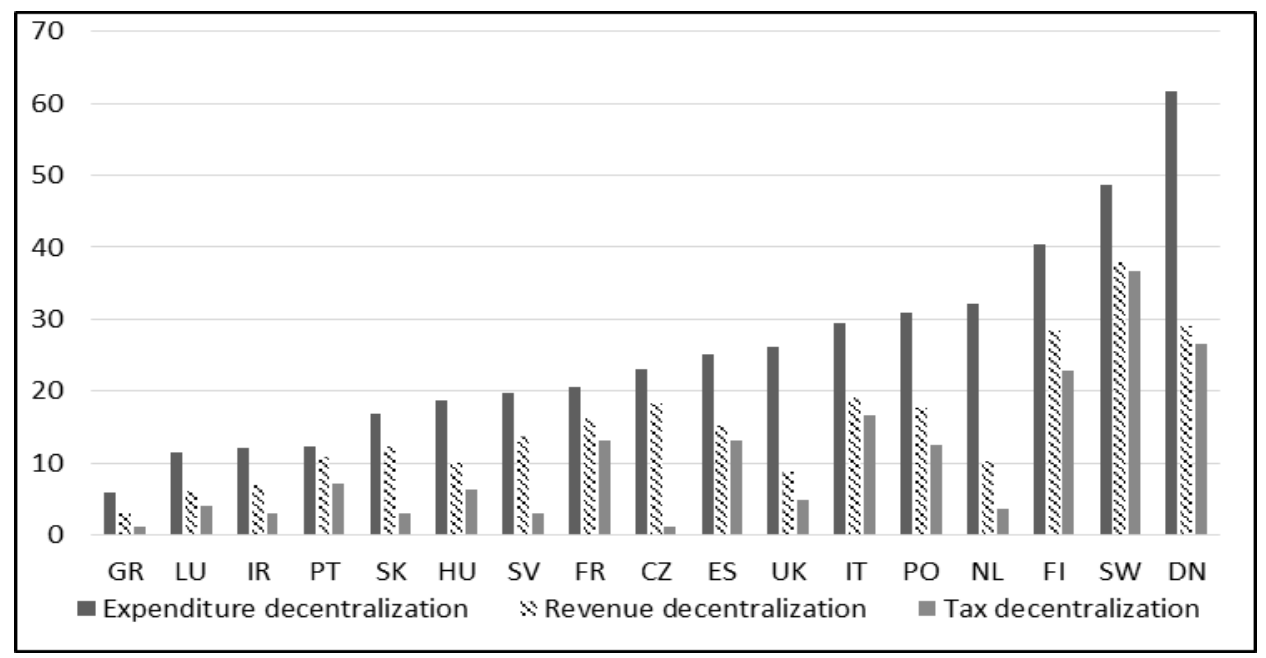

Source: Author's compilation based on data from OECD.

Sub-central expenditure share averaged around $26 \%$ in 2012, with values ranging between $64 \%$ for Denmark and $6 \%$ for Greece, while the revenue decentralisation share is at around $18 \%$, with values between $38 \%$ for Sweden and less than $3 \%$ in Greece. Tax revenue 
decentralisation varies from $1 \%$ in Greece and the Czech Republic to $36 \%$ in Sweden, with average value $11 \%$. Expenditures are clearly more decentralized than revenues, with a considerable part of sub-central expenditure covered by intergovernmental grants. While both revenue and expenditure became more decentralized over the past 20 years, expenditure decentralisation outpaced revenue decentralisation, resulting in a higher vertical fiscal imbalance and growing intergovernmental grants (for details look at Halásková and Halásková, 2014; OECD, 2013 or OECD Decentralisation database). Only a few countries - in particular Italy that embarked on a secular decentralisation process and a few Eastern European economies such as Estonia and Poland - underwent considerable changes in sub-central spending and taxation powers. Tax autonomy is extremely low and the freedom of sub-central governments to introduce or to abolish a tax, to set tax rates, to define the tax base, or to grant tax allowances or reliefs to individuals and firms is very limited in countries as the Czech Republic, Ireland or Greece (Szarowská, 2013). Decentralisation appears to converge towards an intermediate level, with a few highly decentralized countries recentralizing and several highly centralized countries devolving fiscal powers to lower government levels.

Reforms to intergovernmental fiscal frameworks can explain a part of the evolution of decentralisation indicators over the past 20 years. The most common fiscal federalism reforms include: the devolution of new responsibilities for public services to the sub-central level, especially in the area of economic affairs and social welfare; the upgrading and amendment of equalisation and other intergovernmental grant systems, particularly a move from earmarked to non-earmarked grants; the introduction or tightening of sub-central fiscal rules; a move from grants to tax sharing; and sub-central tax reforms, mostly entailing a stronger harmonization of central and sub-central tax bases (Blöchliger, 2013).

Across the selected countries, decentralisation appears to be positively associated with GDP per capita levels but negatively associated with real GDP growth (see Figures 3-5). It is necessary to point out that decentralisation ratios as well as real GDP growth and economic performance described by GDP per capita in PPP are expressed as average values, which may affected the findings.

The expenditure decentralisation indicator (EXPD) is defined for each state as the ratio of local and state government expenditure to global total 
general expenditure at general government level plus the total intergovernmental property expenditure. The addition is made because the latter represents payments by one level of government for a service provided by another government level and it essentially avoids consolidation of property expenditure at general government level.

\section{Fig. 3: Expenditure decentralisation $(1995$ - 2012)}
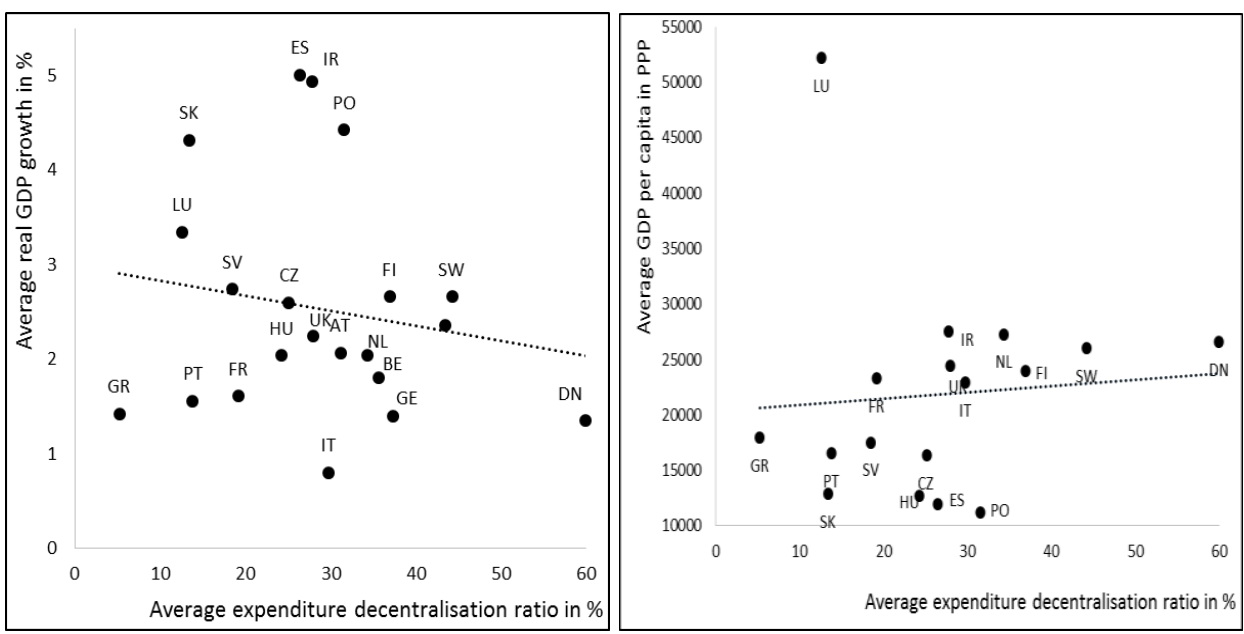

Source: Author's compilation based on data from OECD.

This indicator corresponds to the most approximate measure of the allocation of authority when a subnational government has authority associated with its expenditure implicitly considering that all intergovernmental grants are non-matching or lump-sum grants. 
Fig. 4: Revenue decentralisation $(1995-2012)$
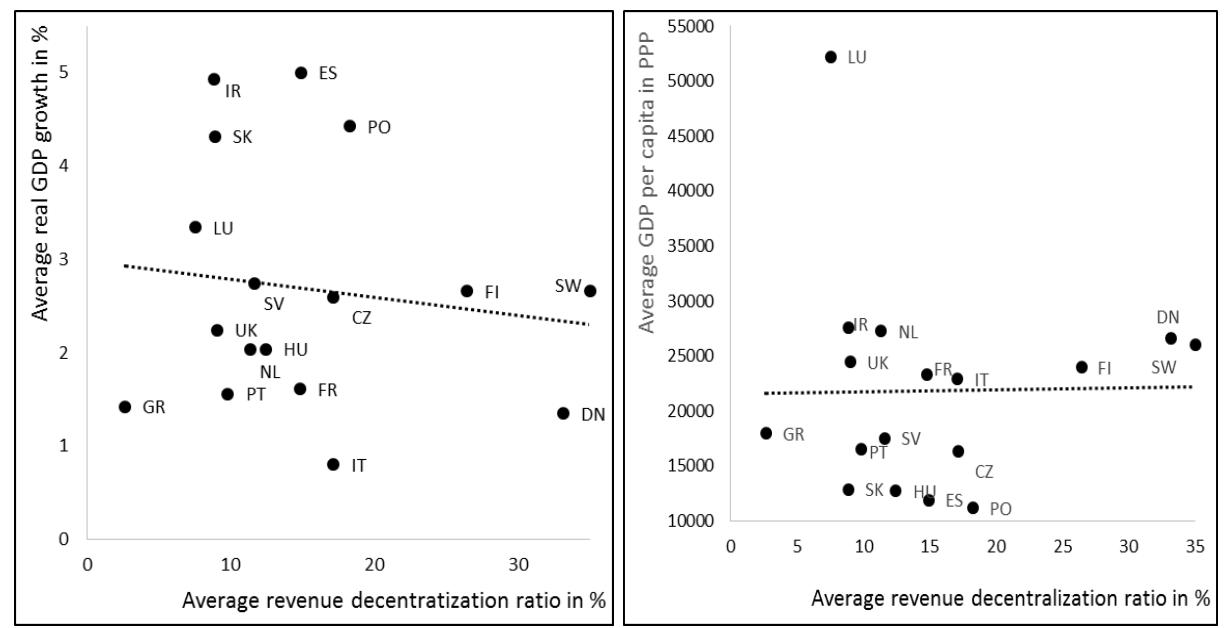

Source: Author's compilation based on data from OECD.

The revenue decentralisation indicator (REVD) is defined for each state as the ratio of own local and state government revenue (total revenue less the intergovernmental transfer revenue of that government level) to total general government revenue.

Finally, tax revenue decentralisation (TAXD) is the ratio, expressing share of sub-central tax revenue to total general government tax revenue. Consolidated total general government revenue is defined and has been calculated as global total revenue at general government level plus the total inter-governmental property income. The addition is made because the latter represents payments by one level of government for a service provided by another government level and it essentially avoids consolidation of property income at general government level. 
Fig. 5: Tax revenue decentralisation $(1995$ - 2012)
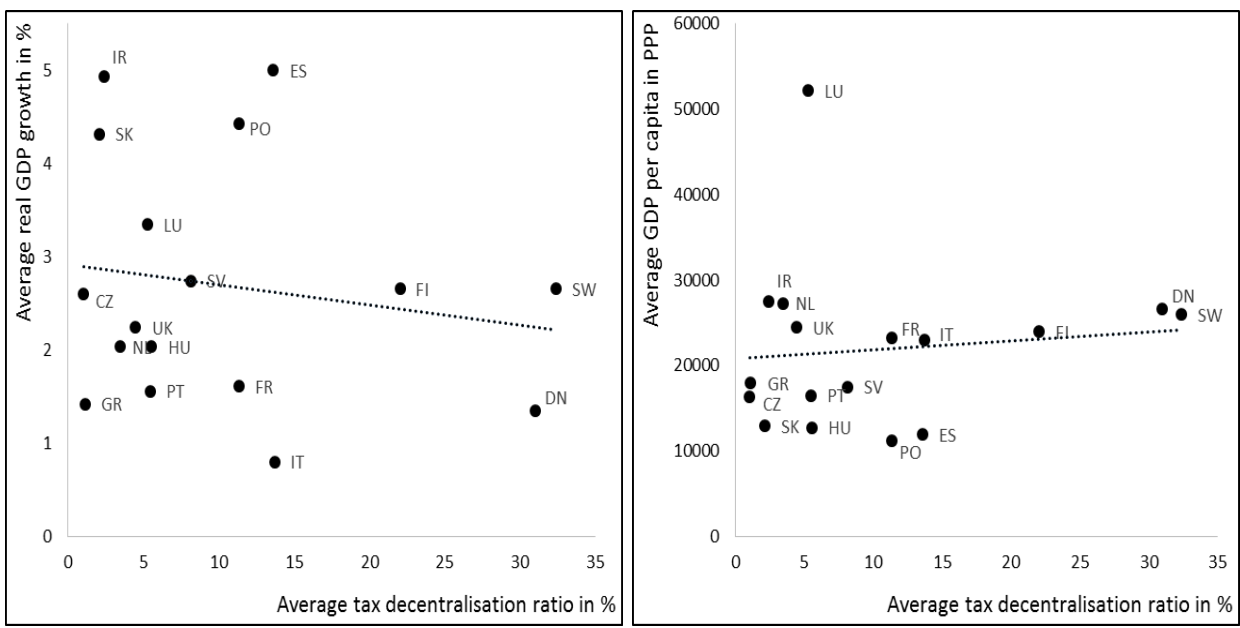

Source: Author's compilation based on data from OECD.

These revenue indicators corresponds to the most common argument of the allocation of authority when the government that collects revenue has authority associated with its own revenue or the tax to be collected (Oates, 1993).

The information provided by Figures $3-5$ should, in any case, be interpreted with caution, as economic growth does not depend exclusively on the degree of fiscal decentralisation of a country (coefficients of determination are very low). The same conclusion is possible to find in Davoodi and Zou (1998), Akai and Sakata (2002), Iimi (2005) or Thornton (2007). The potential influence of the degree of fiscal decentralisation on economic performance may be affected by country differences in political and administrative decentralisation (RodríguezPose and Ezcurra, 2011). As well, the optimal level of decentralisation might differ between a small country with many municipalities and a large country with few regions.

In order to test whether fiscal decentralisation matters for economic performance, there are estimated econometric models expressed in a basic form for real GDP growth in (1) and for GDP per capita in (2). Information criteria (Akaike criterion, Schwarz criterion and Hannan Quinn criterion) identified as the optimal time lag 2 years. Table 1 
presents the most appropriate specifications of models resulting from GMM (results of other estimations are available on request).

Tab. 1: Panel regression estimations (Generalized Method of Moments / Dynamic Panel Data)

\begin{tabular}{|c|c|c|c|c|c|c|}
\hline \multirow{2}{*}{$\begin{array}{l}\text { Dependent } \\
\text { Variable }\end{array}$} & \multicolumn{3}{|c|}{$\triangle G D P$} & \multicolumn{3}{|c|}{$\triangle R G D P$} \\
\hline & Coefficient & $\begin{array}{r}\text { Std. } \\
\text { Error }\end{array}$ & $\begin{array}{r}\mathrm{t}- \\
\text { Statistic } \\
\end{array}$ & Coefficient & $\begin{array}{c}\text { Std. } \\
\text { Error }\end{array}$ & $\begin{array}{r}\mathrm{t}- \\
\text { Statistic } \\
\end{array}$ \\
\hline$\Delta G D P_{(-1)}$ & $0.266^{*}$ & 0.016 & 16.275 & & & \\
\hline$\Delta G D P_{(-2)}$ & $-0.074 *$ & 0.028 & -2.676 & & & \\
\hline$\Delta R G D P_{(-1)}$ & & & & $-0.266^{*}$ & 0.020 & -13.391 \\
\hline$\Delta R G D P_{(-2)}$ & & & & $-0.410 *$ & 0.012 & -33.304 \\
\hline$\triangle E X P D$ & $0.002 *$ & 0.001 & 2.623 & $0.115^{*}$ & 0.036 & 3.199 \\
\hline$\Delta R E V D$ & $-0.008^{*}$ & 0.002 & -5.372 & $-0.484^{*}$ & 0.083 & -5.801 \\
\hline$\triangle T A X D$ & 0.002 & 0.002 & 1.569 & -0.959 & \begin{tabular}{|l|}
0.104 \\
\end{tabular} & -9.256 \\
\hline Observations & \multicolumn{3}{|c|}{255} & \multicolumn{3}{|c|}{255} \\
\hline Mean & \multicolumn{3}{|c|}{0.016} & \multicolumn{3}{|c|}{0.241} \\
\hline $\begin{array}{l}\text { S.D. dep. } \\
\text { var. }\end{array}$ & \multicolumn{3}{|c|}{0.043} & \multicolumn{3}{|c|}{3.569} \\
\hline S.E. of reg. & \multicolumn{3}{|c|}{0.044} & \multicolumn{3}{|c|}{3.366} \\
\hline
\end{tabular}

Source: Author's calculation based on data from OECD.

Note: Symbol * denotes statistical significance at the $1 \%$ level.

The main results concerning the effect of fiscal decentralisation on economic development indicate the relationship is stronger for revenue decentralisation than for expenditure decentralisation, suggesting that a budget's revenue side is a better indicator for the link between fiscal frameworks and economic development than the expenditure side. The most important difference is in a way of influencing the economic development. Table 1 shows that the estimated coefficients on expenditure fiscal decentralisation are positive and statistically significant (even at the $1 \%$ level). This finding confirms that increase of state and local expenditure contributes to the economic growth and economic performance. Contrary, revenue decentralisation seems to have negative influence on economic development, as coefficients are negative 
and statistically significant during the reporting period. Tax revenue decentralisation has negative but statistically insignificant impact on economic growth and economic performance in the observed countries.

These findings are extremely interesting as the relationship between the different decentralisation measures and economic performance evolves in opposite directions and countries tend to increase revenue fiscal decentralisation over the last years. Obtained results also suggest that effect of fiscal decentralisation is higher and more intensive on economic level increase than on GDP growth.

In terms of subnational expenditure and revenues, the results are in line with the findings of other empirical studies on fiscal decentralisation and economic growth, such as Akai and Sakata (2002), Thiessen (2003), Iimi (2005) or Rodríguez-Pose and Krøijer (2009), but opposite as Zhang and Zou (1998), Rodden (2002) or Rodríguez-Pose and Ezcurra (2011). The variety is generated due to differences used in econometric models, country samples, observation periods and considered variables.

\section{Conclusion}

This paper investigates the impact of fiscal decentralisation on a longterm economic development. The aim of the paper was to provide direct empirical evidence on fiscal decentralisation and economic development in selected European countries in a period 1995 - 2012. The research was performed on a panel, which contains 17 unitary countries. The analysis used data taken from OECD Fiscal Decentralisation Database and OECD. Since fiscal decentralisation has many dimensions, the following indicators were used in the empirical analysis: expenditure decentralisation, revenue decentralisation and tax revenue decentralisation. The empirical tests relating decentralisation and economic performance were based on dynamic panel data model, the estimation used Generalized Method of Moments.

Results suggest that the degree of decentralisation varies widely across country sample but has changed only fractionally over the reported period. Tax revenue decentralisation varies from $1 \%$ in Greece and the Czech Republic to $36 \%$ in Sweden, with average value $11 \%$. Revenue decentralisation shares about $18 \%$, with values between $38 \%$ for Sweden 
and $3 \%$ for the Greece in 2012. Conclusively, expenditure side is more decentralized than revenues (sub-central government expenditure share averaged around $26 \%$, with values ranging between $61 \%$ for Denmark and $6 \%$ for Greece), with a considerable part of sub-central expenditure covered by intergovernmental grants.

Findings of dynamic panel analysis confirm positive and significant impact of expenditure decentralisation on economic growth and economic performance. Although the relationship is stronger for revenue decentralisation than for expenditure decentralisation, revenue decentralisation seems to have negative influence on economic development, as coefficients are negative and statistically significant during the reporting period. Tax revenue decentralisation has also negative but statistically insignificant impact on economic activity in the observed countries.

Based on the empirical results, study suggests that state and local governments should be given more autonomy and authority in fiscal expenditure matters. Generally, decentralisation is often associated with increased degrees of policy innovation, greater transparency, and better capacity of governments to adapt policies to local needs. On the other hand, the evidence did not confirm revenue decentralisation expectation about the ability of local governments to generate their own revenues and promoting fiscal responsibility and incentivize them.

\section{References}

Akai, N. - Sakata, M. (2002): Fiscal decentralisation contributes to economic growth: evidence from state-level cross-section data for the United States. Journal of Urban Economic, 2002, vol. 52, no. 1, pp. 93 108.

Arellano, M. - Bond, S. (1991): Some tests of specification for panel data. The Review of Economic Studies, 1991, vol. 58, no. 2, pp. 277-297.

Baskaran, T. - Feld, L.P. (2013): Fiscal decentralisation and economic growth in OECD countries. Is there a relationship? Public Finance Review, 2013, vol. 41, no. 4, pp. 421-445.

Bird, R. M. - Wallich, C. I. (1993): Fiscal decentralisation and intergovernmental relations in transition economies. World Bank Policy Research Working Paper, no. 1122, 1993. 
Szarowská, I.: Fiscal Decentralisation and Economic Development in Selected Unitary European Countries.

Blöchliger, H. (2013): Decentralisation and economic growth-Part 1: How fiscal federalism affects long-term development. OECD Working Papers on Fiscal Federalism no. 14, 2013.

Blöchliger, H. - Égert, B. (2013): Decentralisation and economic growth - Part 2: The impact on economic activity, productivity and investment. OECD Working Papers on Fiscal Federalism no. 15, 2013.

Brennan, G. - Buchanan, J. (1980): The power to tax: Analytical foundations of a fiscal constitution. Cambridge, Cambridge University Press, 1980.

Davoodi, H. - Zou, H. (1998): Fiscal decentralisation and economic growth: A cross-country study. Journal of Urban Economics, 1998, vol. 43, no. 2, pp. 244-257.

Gemmell, N. - Kneller, R. - Sanz, I. (2013): Fiscal decentralisation and economic growth: Spending versus revenue decentralisation. Economic Inquiry, 2013, vol. 51, no. 4, pp. 1915-1931.

Halásková, M. - Halásková, R. (2014): Impacts of decentralisation on the local government expenditures and public services in the EU countries. Lex Localis - Journal of Local Self Government, 2014, vol. 12, no. 3, pp. 623-642.

Hansen, L. P. (1982): Large sample properties of Generalized Method of Moments Estimators. Econometrica, 1982, vol. 50, no. 4, pp. 1029-1054.

Iimi, A. (2005): Decentralisation and economic growth revisited: An empirical note. Journal of Urban Economics, 2005, vol. 57, no. 3, pp. 449-461.

Oates, W. E. (1993): Fiscal decentralisation and economic development. National Tax Journal, 1993, vol. 46, no. 2, pp. 237-243.

OECD (2013): Fiscal federalism 2014: Making decentralisation work. Paris, OECD Publishing, 2013.

Rodden, J. (2002): The dilemma of fiscal federalism: grants and fiscal performances around the world. American Journal of Political Science, 2002, vol. 46, no. 3, pp. 670-687.

Rodríguez-Pose, A. - Ezcurra, R. (2011): Is fiscal decentralisation harmful for economic growth? Evidence from the OECD countries. Journal of Economic Geography, 2011, vol. 11, no. 4, pp. 619-643. 
Rodríguez-Pose, A. - Krøijer, A. (2009): Fiscal decentralisation and economic growth in Central and Eastern Europe. London School of Economics and Political Science LEQS Paper no. 12, 2009.

Szarowská, I. (2013): Effects of taxation by economic functions on economic growth in the European Union. In Jircikova, E. - Knapkova, A. - Pastuszkova, E. (eds.): Proceedings of the 6th International Scientific Conference: Finance and the performance of Firms in Science, Education and Practice. Zlin, Tomas Bata University, pp. 746-758.

Tanzi, V. (1995): Fiscal federalism and decentralisation: A review of some efficiency and macroeconomic aspects. In Bruno, M. - Pleskovic, B. (eds.): Annual World Bank Conference on Development Economics. Washington, DC, World Bank, pp. 295-316, 1995.

Thiessen, U. (2003): Fiscal decentralisation and economic growth in high income OECD countries. Fiscal studies, 2003, vol. 61, no. 1, pp. 64-70.

Thornton, J. (2007): Fiscal decentralisation and economic growth reconsidered. Journal of Urban Economics, 2007, vol. 61, no. 1, pp. 6470.

Vasquez, J. - McNab, R. M. (2003): Fiscal decentralisation and economic growth. World Development, 2003, vol. 31, no. 9, pp. 15971616.

Zhang, T. - Zou, H. (1998): Fiscal decentralisation, public spending, and economic growth in China. Journal of Public Economics, 1998, vol. 67, no. 2, pp. 221-240. 


\title{
Fiscal Decentralisation and Economic Development in Selected Unitary European Countries
}

\begin{abstract}
The article provides direct empirical evidence on fiscal decentralisation and economic development in selected European countries in a period 1995-2012. The research (based on data taken from OECD Fiscal Decentralisation Database and OECD) is performed on a panel, which contains 17 unitary countries. Explanatory variables are not examined in individual regressions, but study newly uses Generalized Method of Moments. For a model specification, Dynamic Panel Data Model Wizard is applied. Results of dynamic panel analysis suggest positive and statistically significant impact of expenditure decentralisation and stronger but negative effect of revenue decentralisation on economic development. Effect of tax decentralisation seems to be negative but statistically insignificant. These findings are enormously interesting as the relationship between the different decentralisation measures and economic performance evolves in opposite directions and countries tend to increase revenue fiscal decentralisation over the last years.
\end{abstract}

Key words: Fiscal decentralisation; Economic growth; Dynamic panel data.

JEL classification: E62, H71, H72, H77 